\title{
Insights of Biomedical Research
}

\section{An Approximate Overview of COVID-19 Treatment Approaches by Registered Physicians of Bangladesh}

\author{
Farzana Rashid, Md. Ashrafuzzaman*, SK Laila Ayesha, Sadia Tanzim Islam, Niaz Mahmud \\ and Md. Asadur Rahman
}

Department of Biomedical Engineering, Military Institute of Science and Technology (MIST), Bangladesh

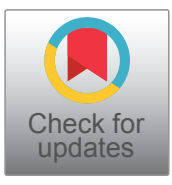

\begin{abstract}
Objectives: With the other countries around the world, Bangladesh is also fighting against the COVID-19 pandemic about which the current treatment and the medication procedure are not revealed worldwide. The aim of this study is to reveal the approximate treatment approaches served by the registered physicians of Bangladesh, especially for the last three months of coronavirus pandemic situation.
\end{abstract}

Study design: The study design was set by generating questionnaires like multiple choice questions and dichotomous questions based on the current perspective of commonly used and different scholarly suggestions for treating corona patients.

\begin{abstract}
Methods: The working methodology was based on both qualitative research and descriptive research by evaluating the observed facts and explains the reasons behind them. Online Google questionnaire survey forms were used to collect data from the randomly picked fifty registered doctors (team leaders) of Bangladesh who are serving corona patients either in government or private health sectors during the last three months. The physicians selected have licenses from Bangladesh Medical and Dental Council (BMDC) and are authorized to prescribe medicines to COVID patients. Concerning our study, the physicians selected are specialized in medicines and mostly are Professors at different medical colleges or medical universities.
\end{abstract}

Results: According to their clinical observations and practice experiences, this study found that Bangladeshi registered doctor's treatment approaches for COVID-19 patients are scientifically co-related with the recent different researchbased work on treatment protocol to combat this coronavirus pandemic situation.

Conclusions: Eventually our concluding remarks are regardless of various limitations in the health sectors of Bangladesh, the physicians have accurately followed the current research and WHO guidelines and are unconditionally serving a country of 165 million people for saving the nation from this deadly virus.

Keywords

COVID-19, Treatment approaches, Questionnaire-based survey, Registered physicians of Bangladesh, WHO guidelines

\section{Introduction}

Bangladesh is one of the heavily populated countries in the world. According to the latest, United Nations data estimated population of Bangladesh is 164.6 million in mid-year of 2020 . About 3,277 people live in per meter squares of this country. Bangladesh has been facing different types of problems due to its extended population. Among them, health problems are one of the major issues in this largely populated country. After first detecting the coronavirus in Wuhan, China in December 2020, it spreads almost 213 counties and territories including Bangladesh. From the given announcement by WHO as coronavirus pandemic on $11^{\text {th }}$ March 2020 until $10^{\text {th }}$ September 2020, the total death in the world is 911,241 against the confirmed cases are 28,211,111. Meanwhile, in our country from the first detected confirmed case was only three on $8^{\text {th }}$ March 2020, and five months later the confirmed cases become 332,970 among them total death 4,634 and recovered 233,550 [1]. The registered physicians of the Republic of Bangladesh have played their roles by providing their

*Corresponding author: Md. Ashrafuzzaman, Department of Biomedical Engineering, Military Institute of Science and Technology (MIST), Mirpur Cantonment, Pallabi, Dhaka, 1216, Dhaka, Bangladesh

Accepted: December 07, 2020

Published online: December 09, 2020

Citation: Rashid F, Ashrafuzzaman , Ayesha SKL, et al. (2020) An Approximate Overview of COVID-19 Treatment Approaches by Registered Physicians of Bangladesh. Insights Biomed Res 4(1):125-138 


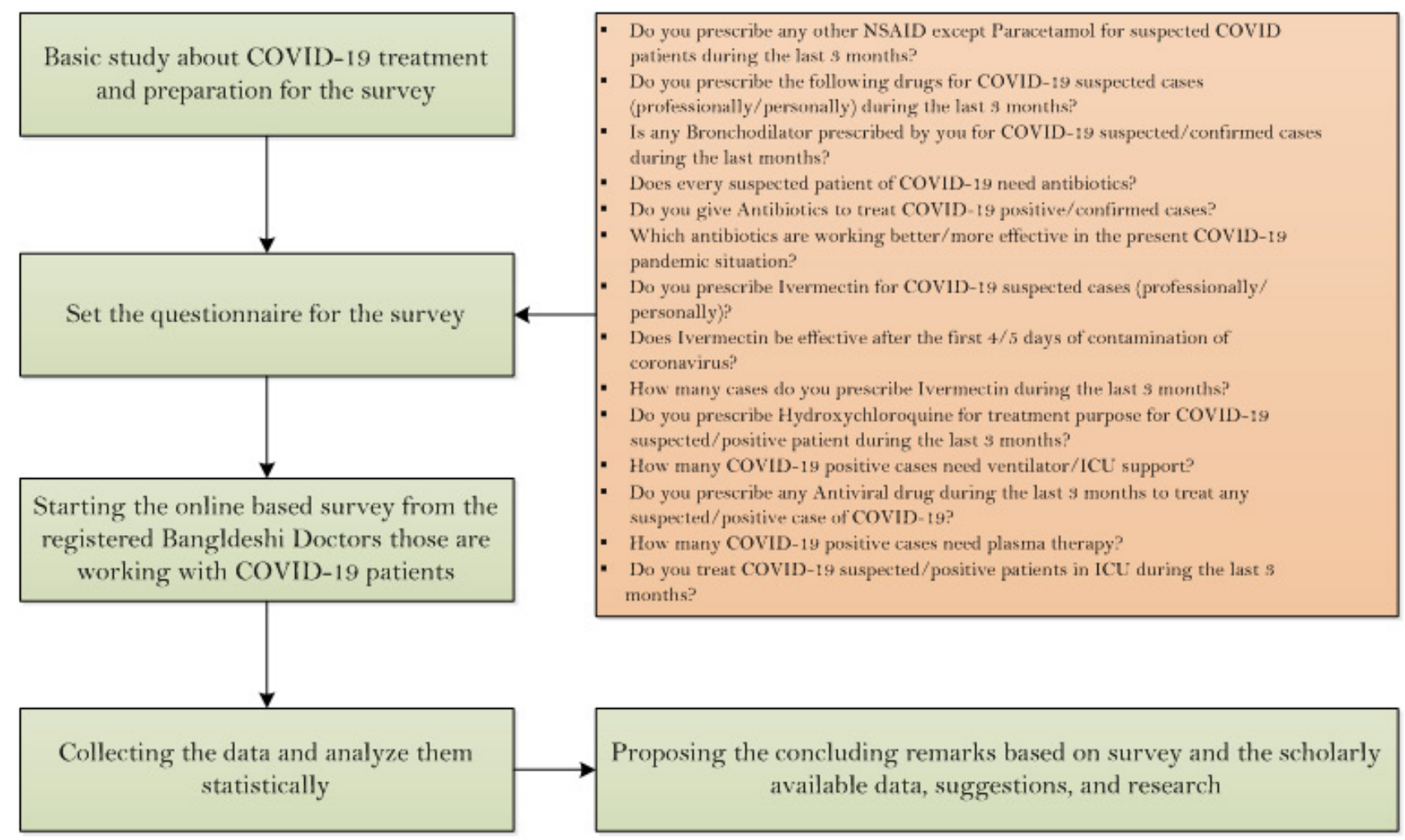

Figure 1: Summarized study methodology with the survey questions.

service to patient by different ways such as public, private, telemedicine, NGO, etc. Due to the fear of contamination about most of the suspected cases are taking their treatment from home by taking telemedicine service until unless become serious. However, since $70 \%$ of the population in our country lives in the rural areas, they are mostly depended on the community and union level facilities under Upazilla health Complex, so both serious and nonserious cases are treated by these facilities. In this paper, we share our experience of online questionnaire surveys on registered doctors of Bangladesh over the last three months of the ongoing coronavirus pandemic situation. The target of this research was to explore the overall approximate treatment given by them and what extends that medicine was effective on Covid-19 by exploring the pharmacodynamic properties and benefits of widely prescribed medicines.

\section{Study Methodology}

The study is based on both qualitative research and empirical research. Ultimately, we are trying to do analytical research by evaluating the observed facts and explain the reasons behind them. In this study, both primary and secondary data are used for analysis of the variable. In general, practicing by means of categorical/qualitative data that focuses on experience of registered physician of Bangladesh having no magnitude; and expressed as percentage. The survey link was active from June 2020 to August 2020 and the data collection was closed once fifty registered doctors have given their informed consent to participate on this survey [2]. Due to lockdown and movement restriction a Google questionnaire form was given to them online where they gave their informed consent to participate this survey and submitted this form according to their clinical observation and practice experience of treating COVID-19 patient in Bangladesh. The questionnaire form was sent to those physicians only who are registered under Bangladesh Medical and Dental Council (BMDC) with specialization focused on medicine. The questionnaires set has been created on the basis of current perspective of commonly used drugs for treating corona patient as well as exploring different academic articles, google scholar, Research Gate, etc. using different "Boolean operators" such as AND \& OR [2-4]. The study methodology is summarized in Figure 1.

\section{Results and Discussion}

\section{Symptomatic treatment}

The most common symptoms of COVID19 are mentioned by the clinicians according to their experience are fever, headache, myalgia, throat pain, runny nose, etc. Symptomatic management such as Paracetamol is prescribed for both fever and pain. Antihistamines are suggested for common cold treatment. NSAID (Non-Steroidal Anti-Inflammatory Drugs) shows their antipyretic effects by inhibiting the cyclooxygenase enzyme that ultimately decreases the prostaglandin in the thermoregulatory center of the brain, reset alter temperature into normal, relief of fever. Paracetamol belongs to NSAID drugs which show the best antipyretic as well as analgesic effects than the rest of NSAID groups. In our survey, we have also found evidence of these facts that Paracetamol was prescribed in $90 \%$ of cases rather than other NSAIDs. The result is given in Figure 2. 


\section{Do you prescribe any other NSAID except Paracetamol for suspected COVID patients during the last 3 months?}

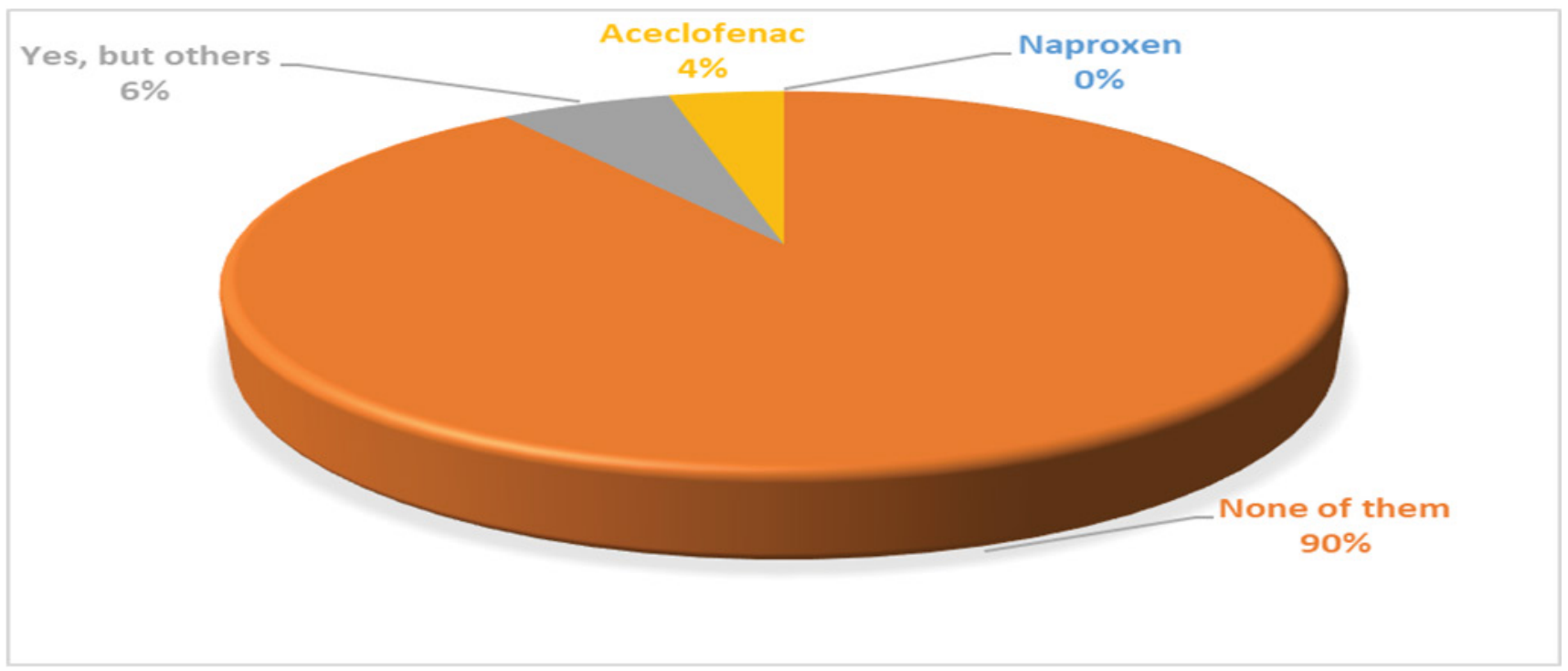

Figure 2: Doctors' responses to analgesic drugs/painkiller.

\section{Do you prescribe the following drugs for COVID-19 suspected cases (professionally/personally) during the last 3 months?}

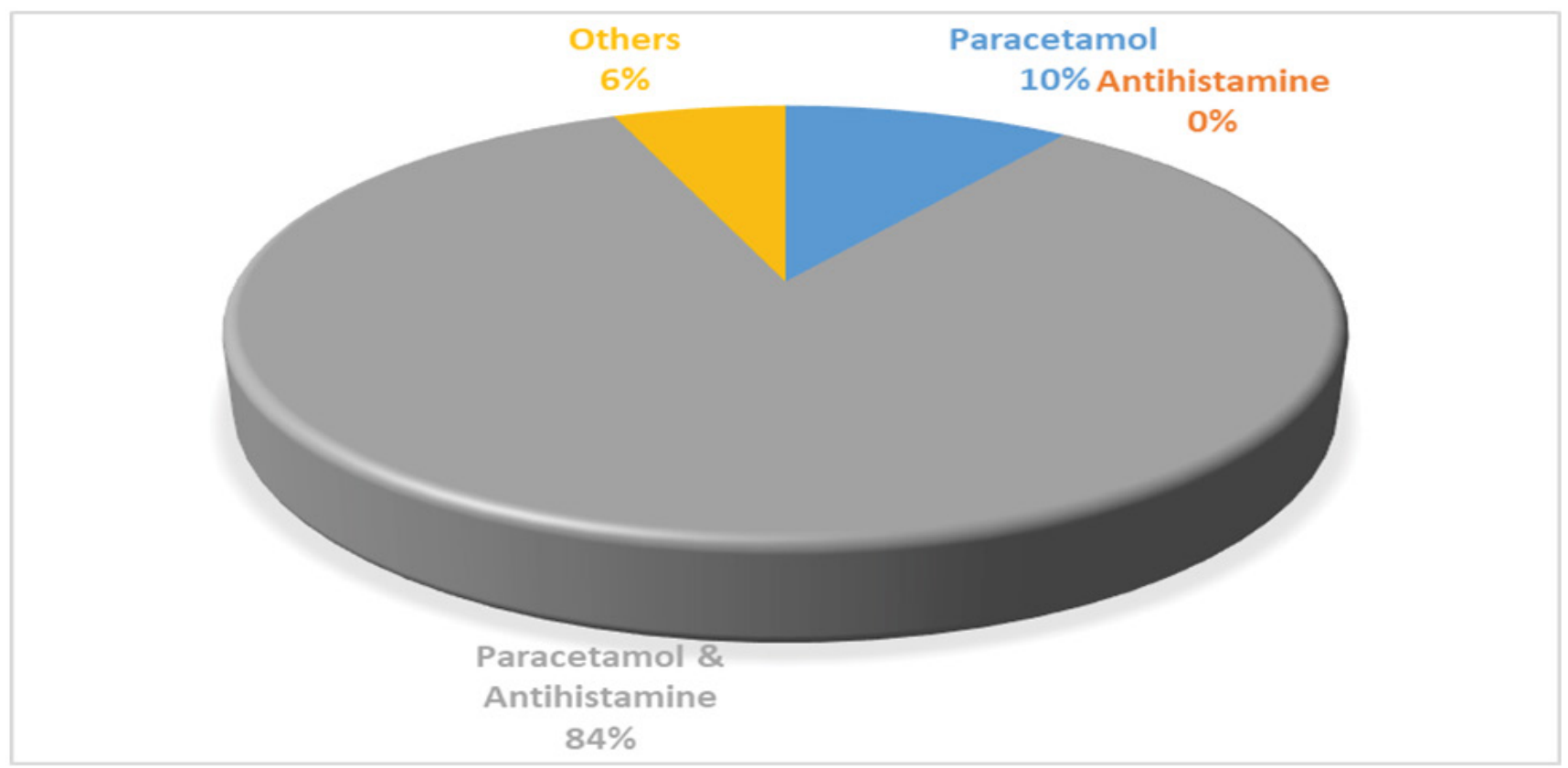

Figure 3: Doctors' responses to commonly prescribed medicine for COVID-19 suspected cases.

For the common cold for example runny nose or any allergic reactions, Antihistamine like Fexofenadine, Loratadine, etc are prescribed by the physician. Histamine is one of the autacoids stores in the body's mast cell and is usually released by degranulation caused by inflammatory stimuli, cold, trauma (Type I hypersensitivity reaction). The justification for using Antihistamines is they inhibit the histamine release by blocking the Histamine type I receptor. Most of the time, fever and common cold occur simultaneously to the COVID-19 suspected patients, so in the preliminary cases, physicians prescribe both together. In $84 \%$ of cases, Paracetamol and Antihistamines are prescribed together in suspected cases of 
COVID-19 by registered physicians of Bangladesh. The survey results in favor of the aforesaid cases are presented in Figure 3.

Dyspnea or difficulty in breathing is another important sign mentioned by the physicians of Bangladesh. Shortness of breathing is caused due to bronchoconstriction of bronchial smooth muscles. In such a case, Bronchodilators act as a reliever. Selective 62 agonist (Salbutamol/Salmeterol), Methyl Xanthine (Theophylline, Aminophylline, Doxyphylline), Anticholinergics (Ipratropium, Tiotropium) are different groups of Bronchodilators available and sometimes prescribed. Among them, Salbutamol which is a short-acting selective 62 agonist is a widely used drug in this COVID-19 pandemic situation about $42 \%$ of cases Salbutamol is solely prescribed and in $20 \%$ of cases, this drug is used with a combination of Ipratropium. Ipratropium is Anticholinergic drug especially used for bronchial asthma patient, this drug blocks the cholinergic muscarinic receptors present in the bronchus and relax the bronchus and helps to improve breathlessness. The survey results are available in Figure 4.

\section{Use of antibiotics}

Since COVID-19 is a respiratory RNA virus, the use of antibiotics for virus treatment is not logical. However, a definite antiviral for COVID-19 treatment is still under research, there is a misconception of the efficacy of antibiotics in coronavirus cases suspected cases in the local population of the country. In our last 3 months survey, we asked questions to registered physicians in Bangladesh about the necessity of the use of Antibiotics in coronavirus infected/suspected cases.

More than $65 \%$ of doctors agreed that there is no need to use antibiotics in viral cases. Antibiotics are used primarily against bacteria not against the virus. The use of antibiotics is not stopped for COVID-19 patient because coronavirus affected individuals face weakening immunity system that initiates the other bacterial infection to flare up in the human body and worsen the condition. To manage this secondary infection, superinfection antibiotics are prescribed to the COVID-19 positive patients. According to our survey, $82 \%$ of doctors have prescribed Antibiotics and $18 \%$ of doctors do not prescribe antibiotics. These results are given in Figure 5 and Figure 6.

As antibiotics are prescribed by physicians, the questions arise which antibiotics are more effective during their practice on coronavirus pandemic situation in Bangladesh. In our survey opinion, $26 \%$ of doctors have prescribed only Azithromycin, and $18 \%$ were given doxycycline only. Furthermore, the majority of physicians (38\%) are likely to prescribe both Azithromycin and Doxycycline on individual cases according to patients' level of response. Less than $15 \%$ of doctors were choosing other groups of antibiotics to treat COVID-19 patients. This $18 \%$ of participants prefer Ceftriaxone, Amoxicillin, Levofloxacin, Moxifloxacin, Meropenem, or combination mainly with clavulanic acid. Our findings are presented in Figure 7 and Figure 8. The clavulanic acid combination is used because it is a 8 lactamase inhibitor, which helps to increase the spectrum of activity of antibiotics. As antibiotics are mainly used for bacteria, not for the virus; proper justification of using antibiotics has become necessary for our country's random use perspective.

\section{Survey on the usage of ivermectin and hydroxy- chloroquine}

Ivermectin is an anti-parasitic drug derived from avermectin $[5,6]$. Since the avermectin compounds are manufactured by Streptomyces avermitilis, bacteria living in the soil, they

\section{Is any Bronchodilator prescribed by you for COVID-19 suspected/confirmed cases during the last 3 months?}

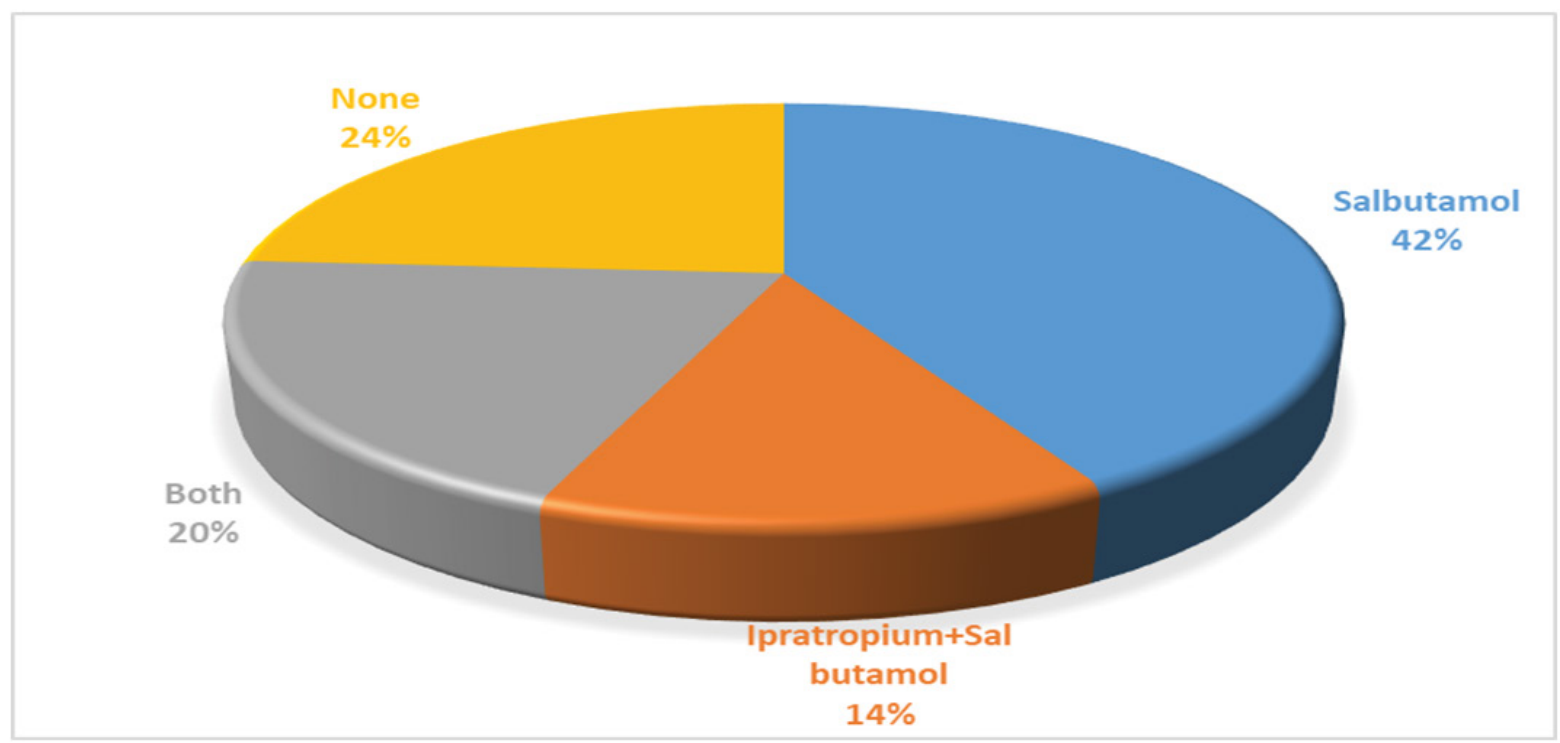

Figure 4: Doctors' suggested prescriptions about the drugs used in shortness of breath/dyspnea. 


\section{Does every suspected patient of COVID-19 need antibiotics?}

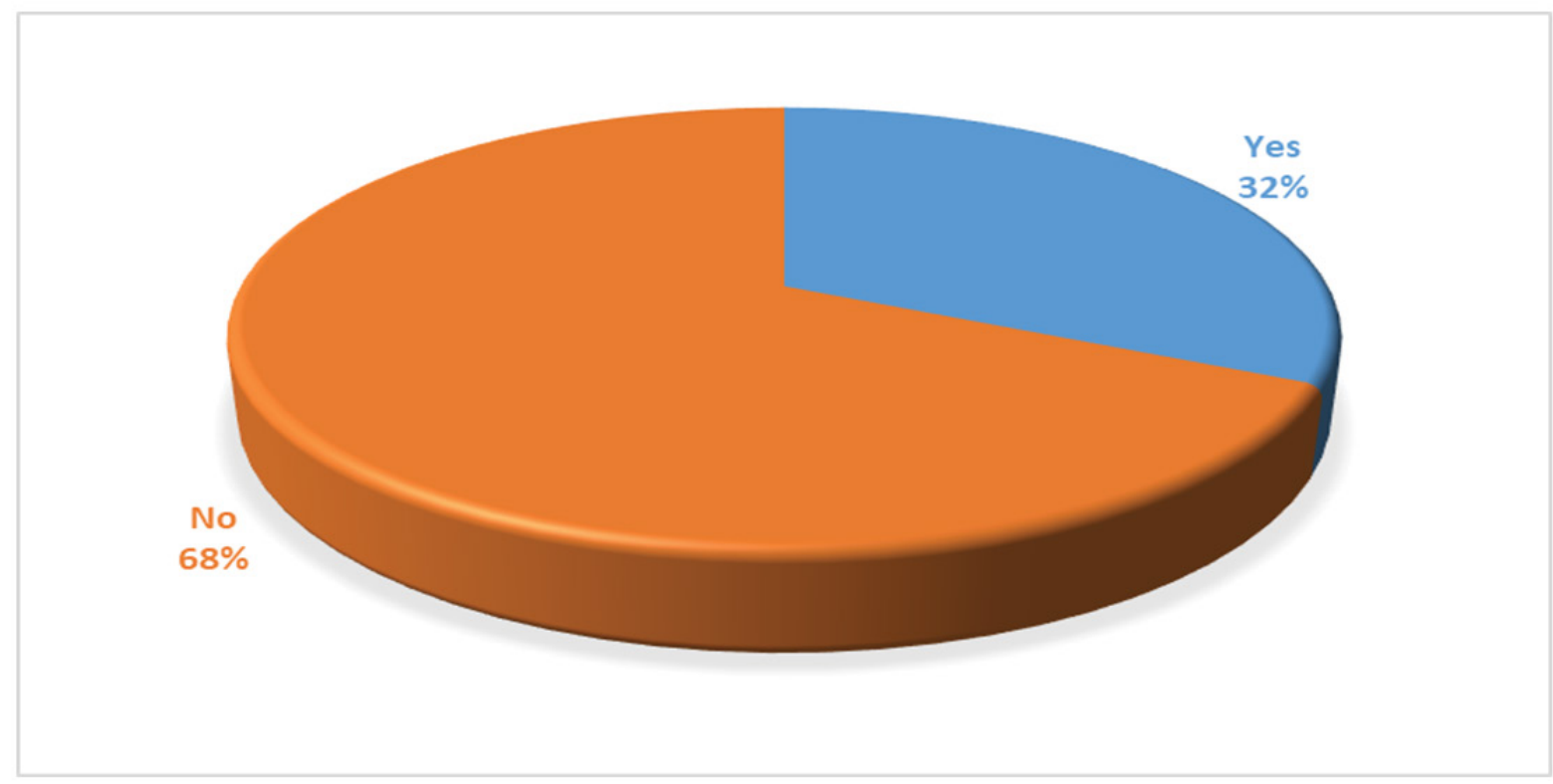

Figure 5: Doctors' responses to antibiotics usage for COVID-19 suspected cases.

\section{Do you give Antibiotics to treat COVID-19 positive/confirmed cases?}

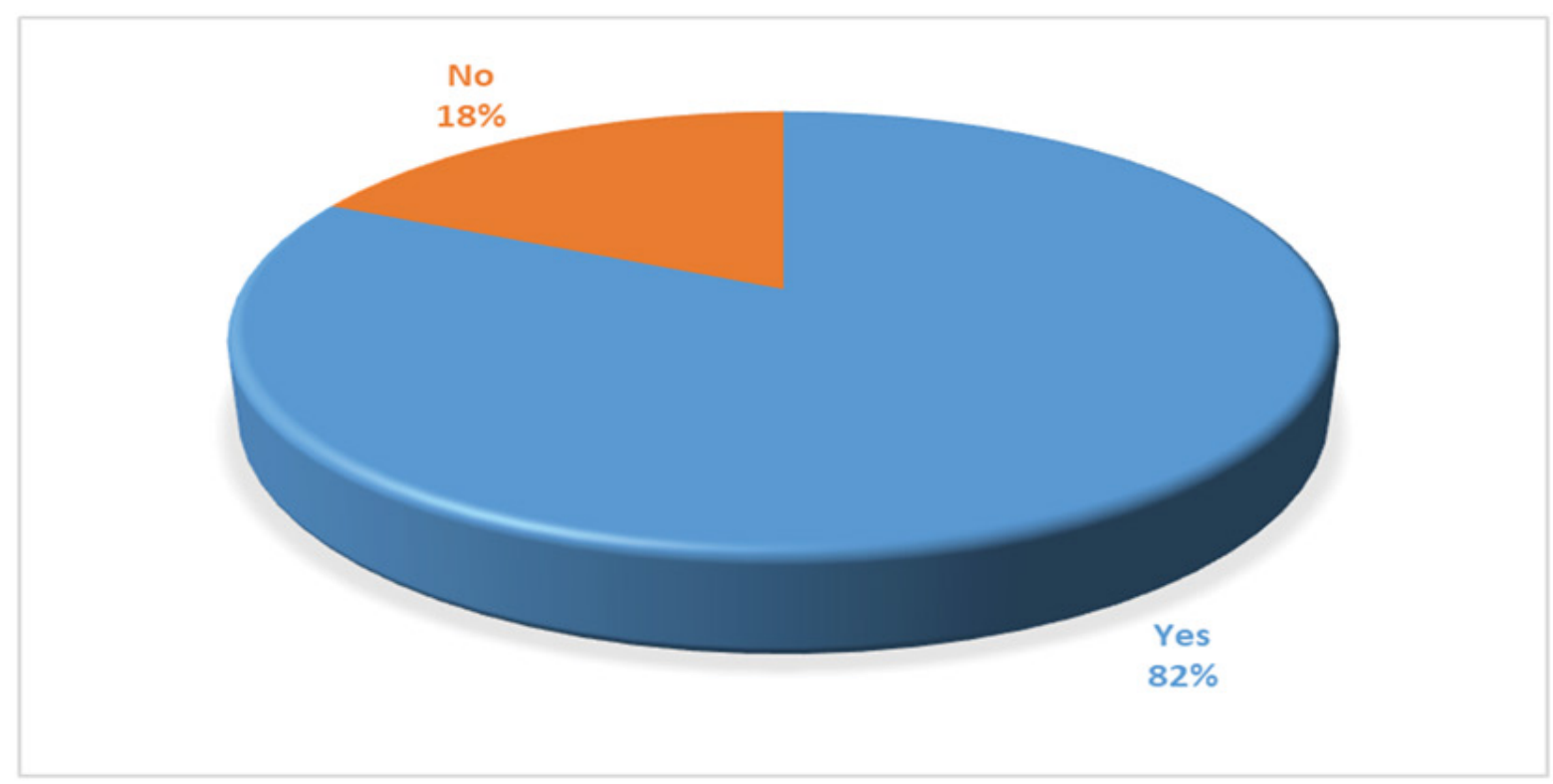

Figure 6: Survey outcomes based on the doctors' responses about antibiotics usage for COVID-19 confirmed cases.

are called avermectins [7]. Ivermectin is a multifaceted drug, besides an anti-parasitic drug, it also shows antiviral activity and is even known to have anticancer activity $[5,6]$.

The mechanism of action of Ivermectin in a COVID-19 affected cell, coronavirus protein binds with the heterodimer of Importin (IMP) $\alpha / 61$, which then moves inside the cell nucleus and lowers antiviral response.

On the other hand, Hydroxychloroquine, an antimalarial drug, is produced by adding a hydroxyl group into chloroquine, a medicine used to treat malaria. However, the modi- fied form is considered to be less toxic than chloroquine [8]. It is also considered that hydroxychloroquine triggers antiviral innate immunity of the host thus, can help in treating autoimmune disease [9]. During virions maturation, it accumulates in the cellular organelles creating an acidic environment to inhibit the replication of different viruses by interfering with endosome/lysosome trafficking or viral protein maturation. These drugs show their antiviral effects by interfering with the glycosylation of angiotensin-converting enzyme2 (ACE2) and blocking virus fusion with the host cell on pre and post-infection conditions which ultimately decrease the binding 


\section{Which antibiotics are working better/more effective in the present COVID-19 pandemic situation?}

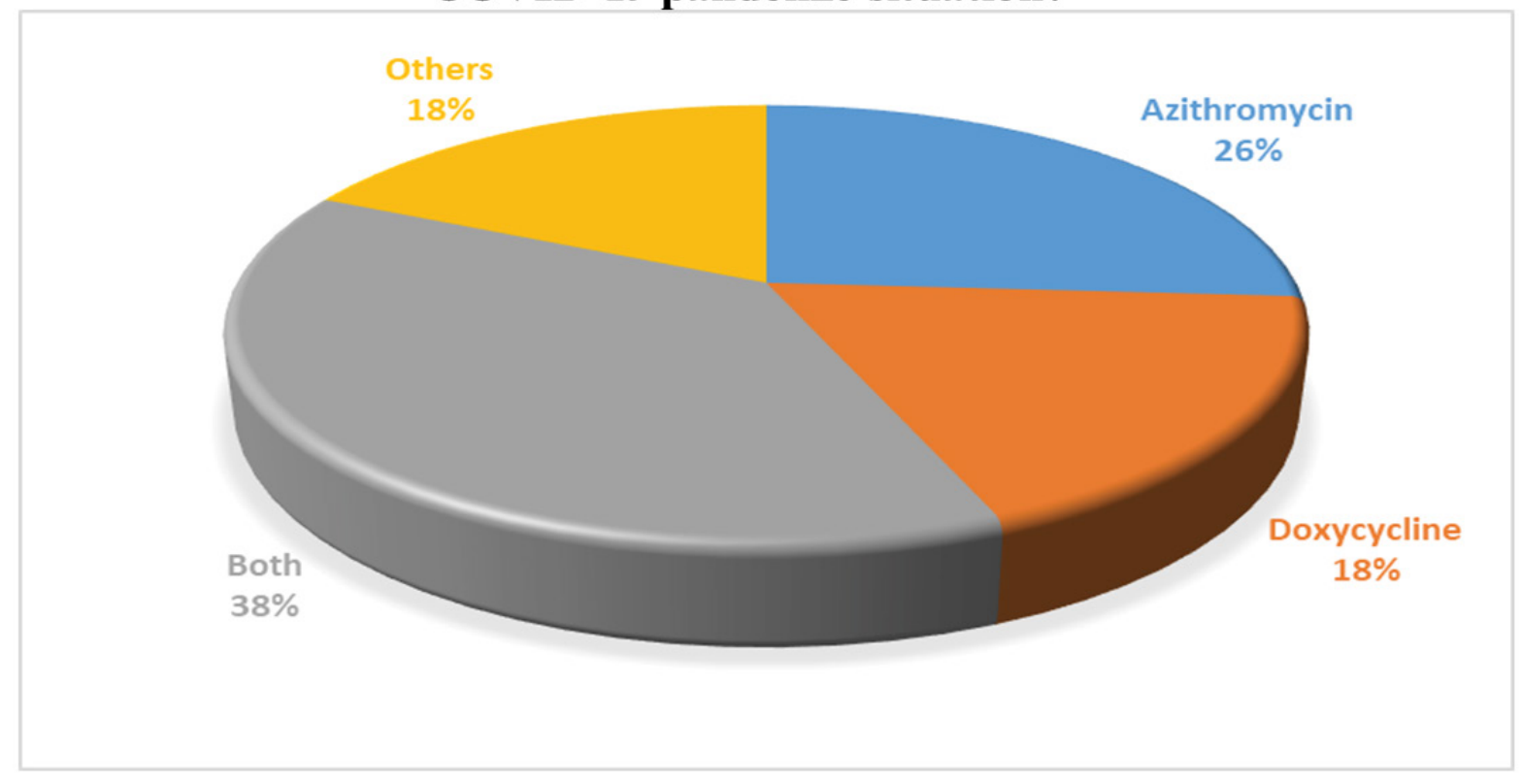

Figure 7: Doctors' responses about commonly used antibiotics and their efficacy on COVID-19 cases.

\section{If you prescribe any other Antibiotics on severe case which one you prefer?(Mention please )}

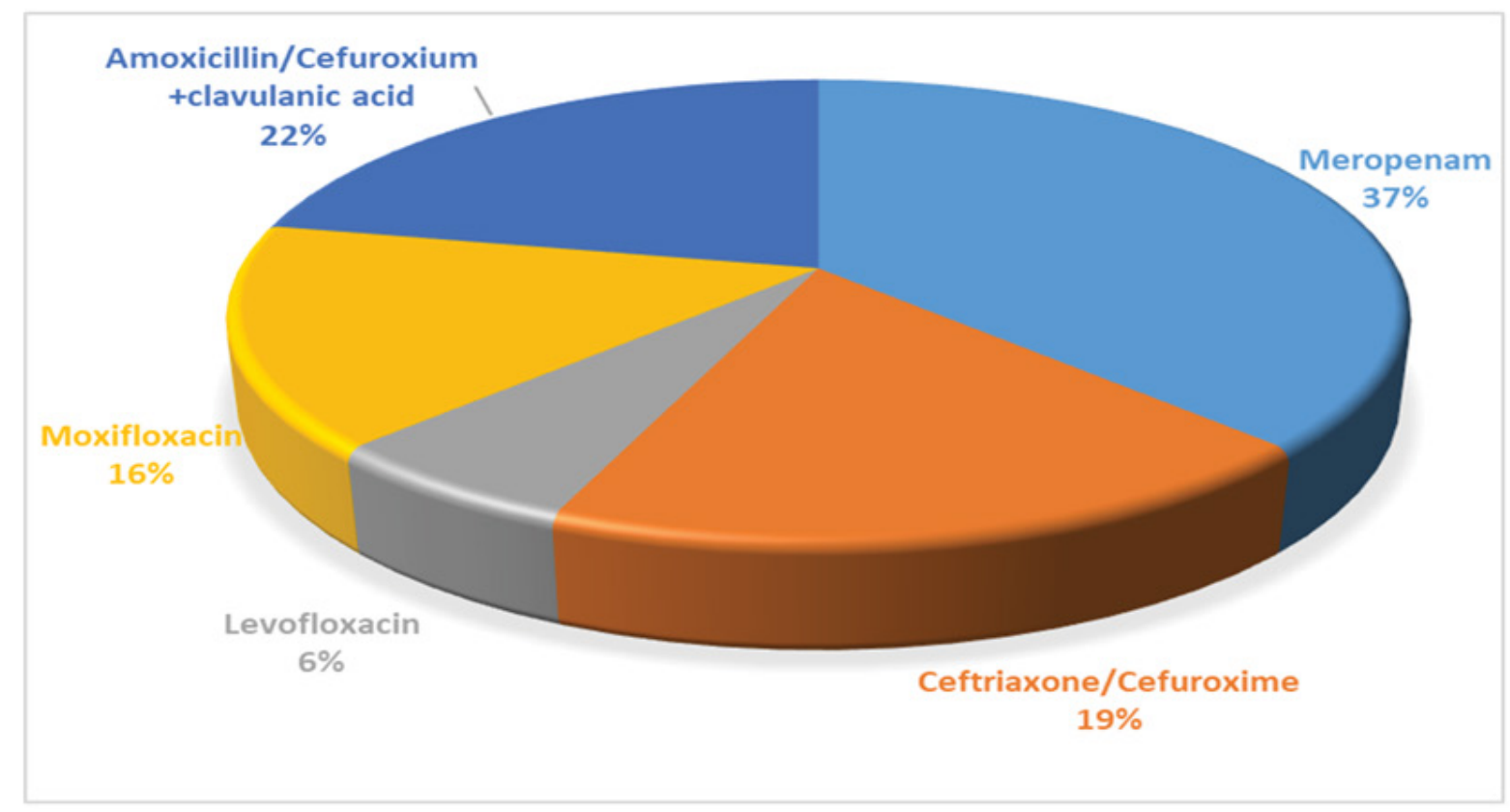

Figure 8: Other antibiotics (except Azithromycin \& Doxycycline) used by registered Bangladeshi physicians.

competence between ACE2 on host cells and the SARS-CoV spike protein. As a result, the binding of host cell receptors and virus is hampered and finally, infection is prevented. It is found that both chloroquine and hydroxychloroquine are possibly harmful to COVID-19 patients $[9,10]$.

A clinical trial is being conducted by another international health research organization in Dhaka, called ICDDR, B (International Centre for Diarrheal Disease Research, Bangladesh). Two main kinds of trials are being conducted - one with a single treatment of ivermectin and another one Ivermectine combined with doxycycline. According to the press release of the organization, this study will take up72 patients from four COVID-19 hospitals aged between 40-65 years, all suffering from mild cases of coronavirus [11,12].

Another comparative study concerning patients with mild to moderate COVID-19 disease from Chakoria Upazilla Health Complex, Cox's Bazar, Bangladesh is now on clinical trial registration, ClinicalTrials.gov NCT04434144 [8,13]. The obser- 
vational study used two different combinations of drugs on two groups of patients. In Group A, 60 patients were given combinations of Ivermectin and Doxycycline and in Group B, 56 patients were treated with Hydroxychloroquine and Azithromycin. A summary of the result is shown in Table 1. It can be seen from the results that, out of 116 patients, the ones treated with Ivermectin and Doxycycline had a higher chance of recovery, with a short duration of recovery and comparatively fewer side-effects. However, the result submitted in the clinical trial is yet to be published on ClinicalTrials.gov [8].
Through our survey, we tried to figure out the actual scenario of usage of ivermectin and Hydroxychloroquine for the COVID-19 patients in Bangladesh. Around 54\% of the practitioners do prescribe Ivermectin on COVID- 19 suspected patients. However, there is still some discrepancy on the fact that if Ivermectin is effective in the initial stages of infection or not. The majority of the doctors only prescribe Ivermectin for less than 10 cases. On the other hand, only $18 \%$ of the physicians prescribed Hydroxychloroquine because of its potentially harmful effects such as the increased risk of cardio-

Table 1: Clinical study design of the proposed clinical trial in Bangladesh.

\begin{tabular}{|l|l|l|}
\hline Results & Group A $(\boldsymbol{n}=\mathbf{6 0})$ & Group B $(\boldsymbol{n}=\mathbf{5 6})$ \\
\hline Recovery rate & $100 \%$ & $96.36 \%$ \\
\hline Duration of recovery & 5.93 days (5-10 days) & 6.99 days (4-12 days) \\
\hline Side effects as reported & Lethargy, nausea, occasional vertigo & $\begin{array}{l}\text { Mild-blurred vision and headache, increase lethargy and dizziness, } \\
\text { occasional mild palpitation, nausea, and vomiting }\end{array}$ \\
\hline
\end{tabular}

\section{Do you prescribe Ivermectin for COVID-19 suspected cases (professionally/personally)?}

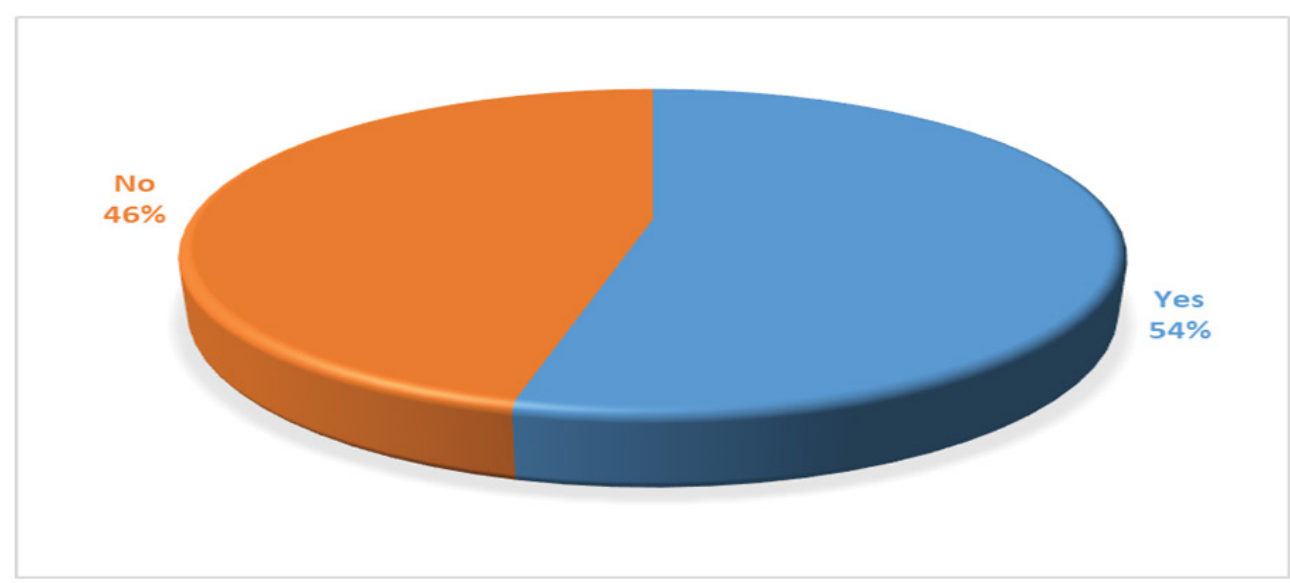

Figure 9: Doctors' responses about Ivermectin usage and efficacy for COVID-19 cases.

Does Ivermectin be effective after the first $4 / 5$ days of contamination of coronavirus?

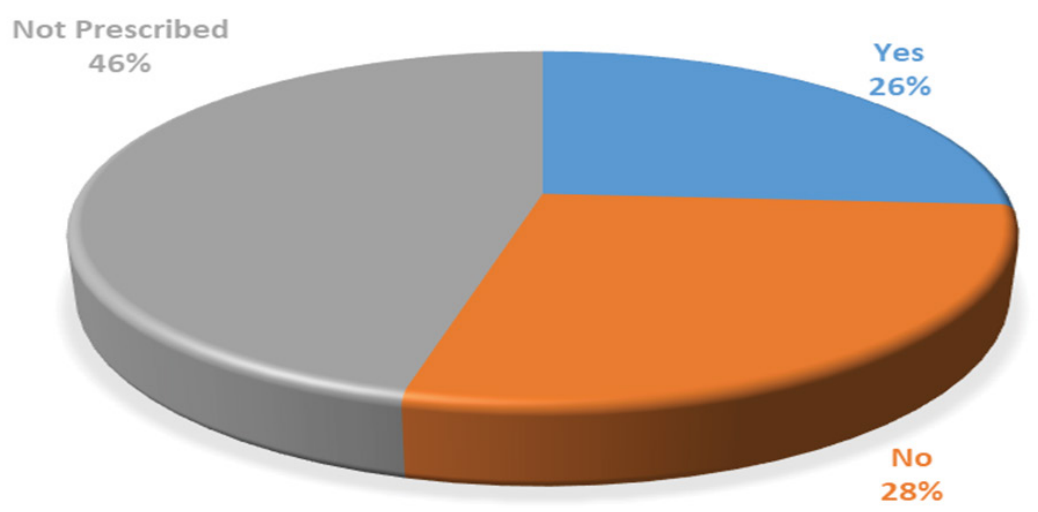

Figure 10: Doctors' responses about Ivermectin prescription and achieved efficacy for COVID-19 cases. 
vascular mortality. The corresponding findings based on our survey are widely presented in Figure 9, Figure 10, Figure 11 and Figure 12, accordingly.

\section{Treatments for ICU patient}

According to our survey responses, about $84 \%$ of doctors act positively towards giving ICU support to at least 10 patients among 100 . Only $12 \%$ said that the number of patients given ICU support is 30 among 100 . The other responses are negligible. Among the 50 doctors, 31 doctors responded to the given question where $23 \%$ recommended that Meropenem, 25\% Enoxaparin, 35\% Steroid, 17\% Antiviral are effective for COVID-19patient. The overall results on the treatment of ICU COVID-19 patients are given in Figure 13 and Figure 14. According to our survey, only $28 \%$ of doctors recommended
Antiviral drugs to treat COVID-19 patients. Those who prescribed the antiviral drug were mentioned their response to our survey.

In the case of antiviral drug prescription, among these $28 \%$ doctors, more than $50 \%$ were prescribed Favipiravir and only $35 \%$ chose Remdesivir to treat COVID-19 positive patient. Though the definite antiviral is still not established by researchers, according to recent research going on around the world these two antivirals selection by the registered doctors of Bangladesh is relatively logical. The overall prescription and the corresponding doctor's responses are given in Figure 15 and Figure 16, accordingly. Since Favipiravir is a prodrug of nucleotide, it inhibits RNA polymerase by stopping viral replication [14]. In a news briefing held in China, a clinician in Shenzen initiated that patients are given Favipiravir

\section{How many cases do you prescribe Ivermectin during the last 3 months?}

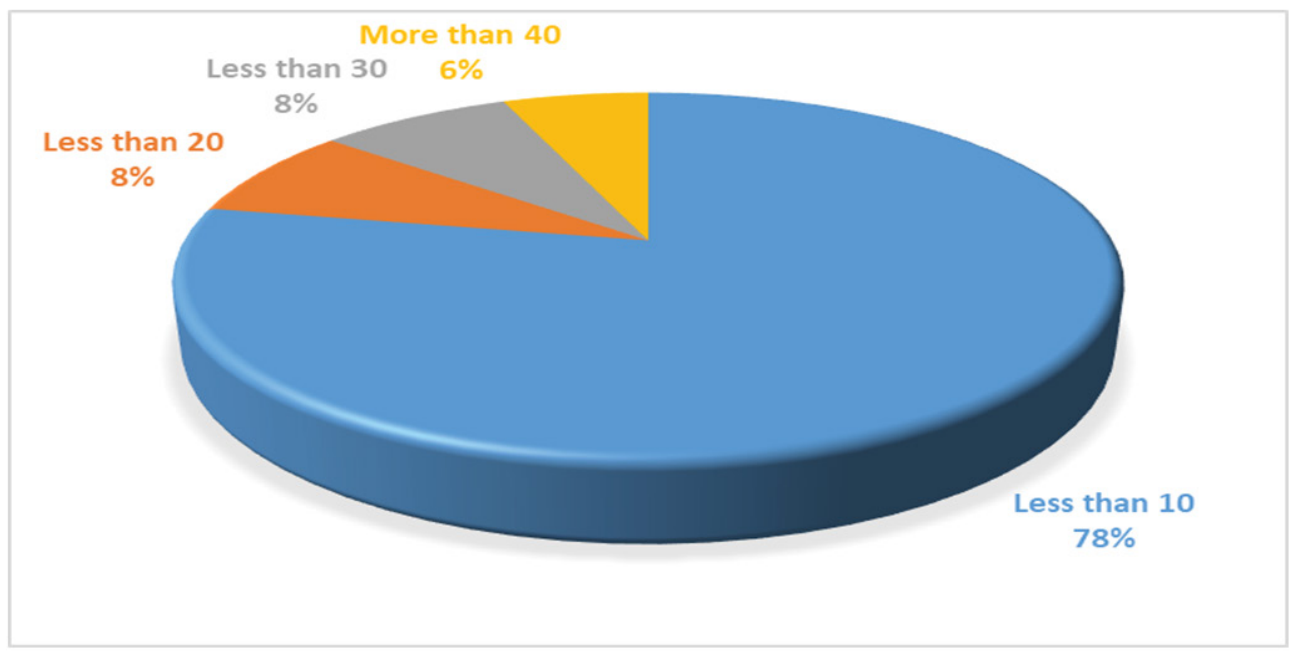

Figure 11: Doctors' responses about prescribed Ivermectin based on the no of cases in COVID-19 treatment.

Do you prescribe Hydroxychloroquine for treatment purposes for COVID-19 suspected/positive patients during the last 3 months?

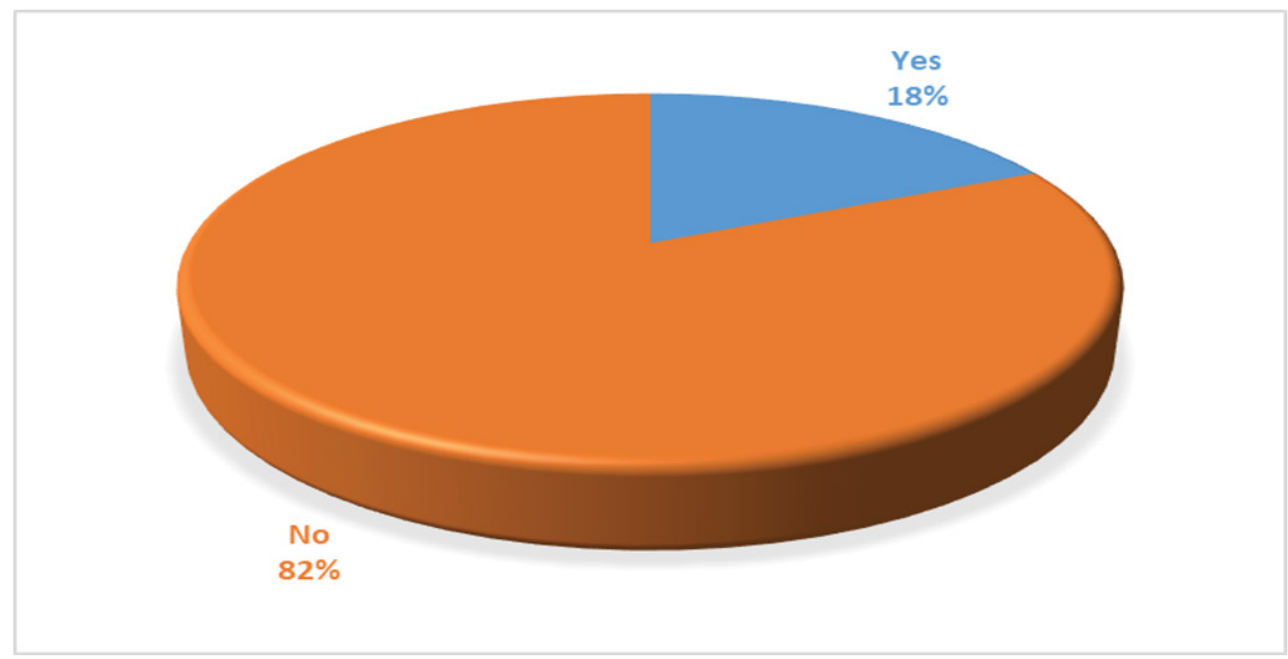

Figure 12: Doctors' responses about Hydroxychloroquine use for covid19 treatment purposes 


\section{How many COVID-19 positive cases need ventilator/ICU support?}

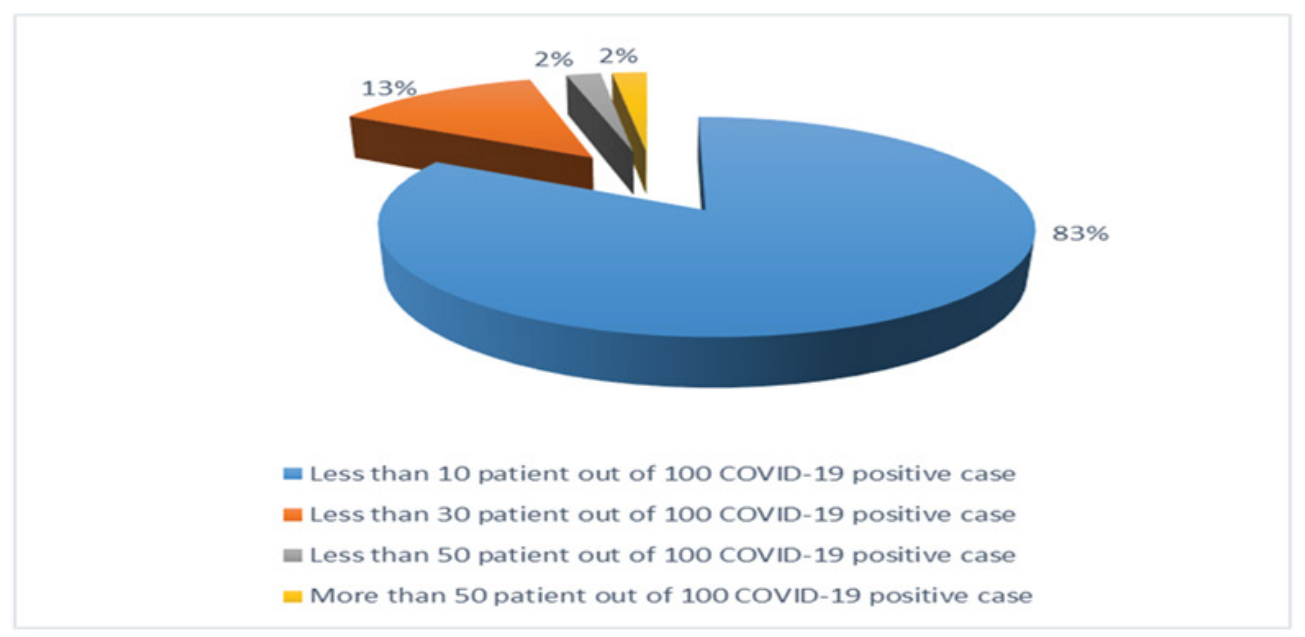

Figure 13: Doctors' responses about ventilator/ICU necessity for covid19 treatment purposes.

\section{In ICU which drugs are effective for COVID-19 positive patients?}

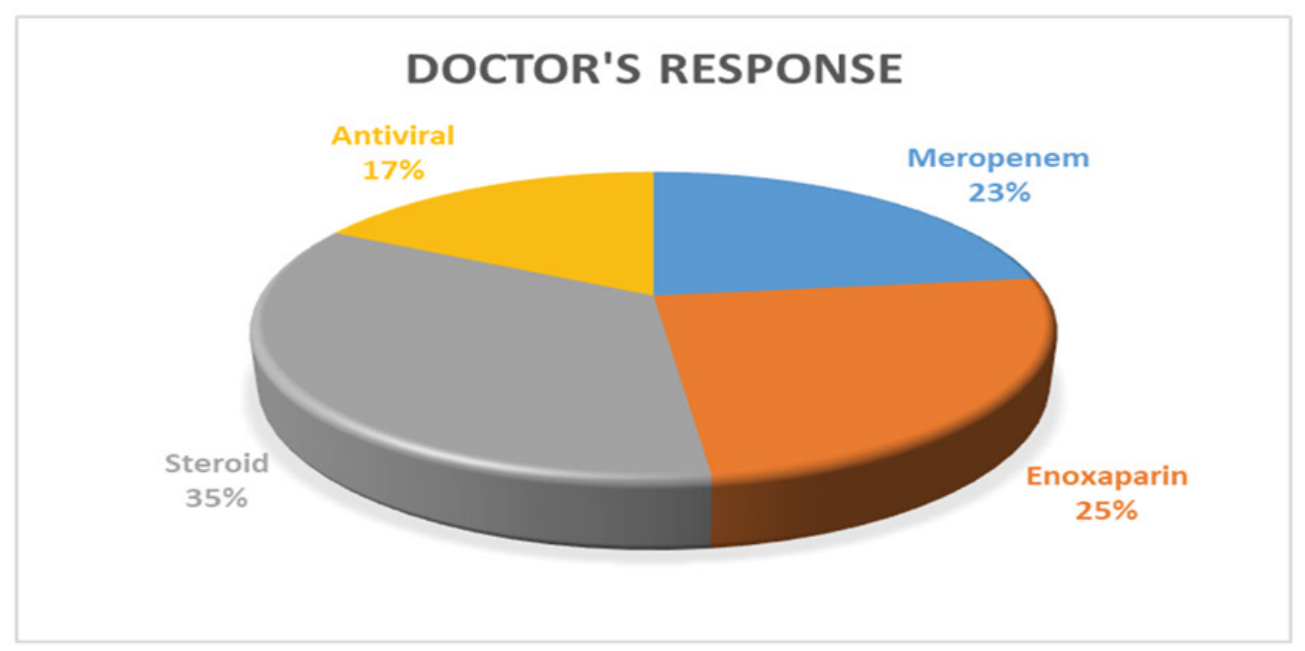

Figure 14: ICU used drugs during Covid19 pandemic by registered Doctors.

medication clear coronavirus RNA after a median of four days [14]. A clinical trial was held in China reports COVID-19 infections taking Favipiravir had a recovery rate after 1 week was $71.4 \%$ [14].

Remdesivir is another most promising antiviral drug that is being used in the current COVID- 19 situation. It is known to restrain the replication of COVID before the SARS-COV-2, 43 animal model of SARS-CoV-1 as well as Middle East Respiratory Syndrome (MERS) [15]. In China, a higher percentage of Remdesivir recipients stopped dosing prematurely by investigators due to severe side effects like gastrointestinal symptoms (nausea, vomiting, and anorexia), aminotransferase, or bilirubin increases, and inferior cardiopulmonary condition [15].

\section{Usages of vitamins and minerals}

Maintaining the body's immunity functions is essential to boost the body's defense mechanism and acts against any types of infection like bacterial, viral, etc. Vitamins and minerals play important roles to maintain the normal functioning of the immune system. For the treatment of COVID-19, the supplementation of these has indicated a positive effect on boosting and modulating immune homeostasis [16]. On nutritional news published by Harvard School of Public Health reported that the duration of staying in the intensive care unit and the patient who need mechanical ventilation was reduced by giving ascorbic acid treatment to them. This positive result was found by multiple meta-analyses and pooled analyses of randomized controlled trials (RCTs) [17].

After the COVID-19 outbreak of Bangladesh, we conducted our survey on the registered physician of Bangladesh almost all of the recommended and prescribed Vitamins and Minerals especially vitamin C (35\%), vitamin D (30\%), and Zinc 


\section{Do you prescribe any Antiviral drug during the last 3 months to treat any suspected/positive case of COVID-19?}

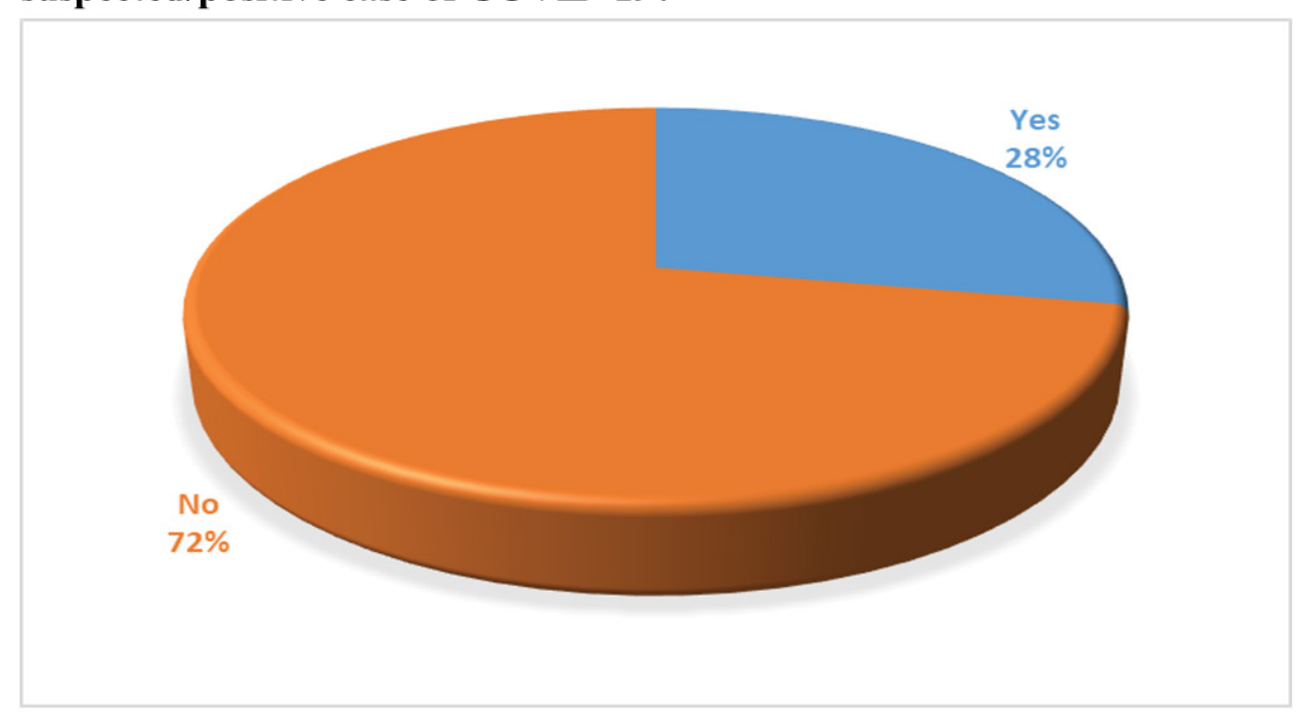

Figure 15: Doctors' responses about the use of antiviral drugs in covid19 suspected/positive cases.

\section{DOCTOR'S RESPONSE}

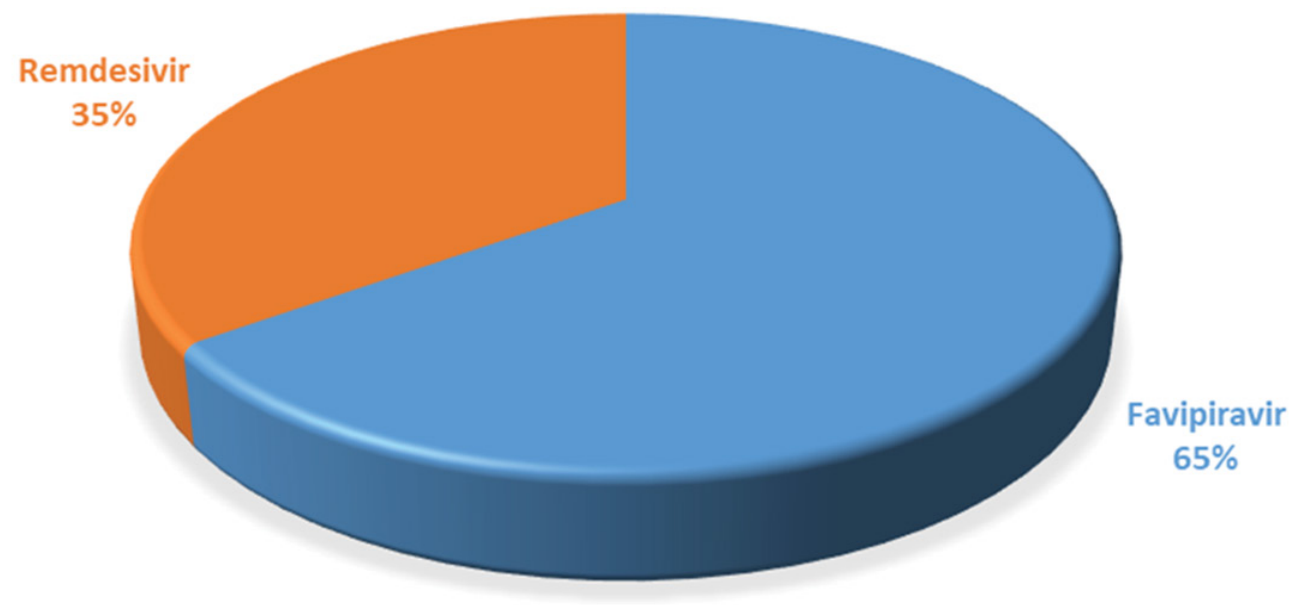

Figure 16: Doctors' responses to recommended antivirals use.

(32\%). This result is given in Figure 17. Only $3 \%$ of doctors were not prescribing any vitamin or mineral because they advised supplementary natural dietary foods containing a rich number of vitamins and minerals.

\section{Plasma therapy}

Plasma therapy is a century-year-old treatment method that can be defined as passive immunization where specific antibodies were sought from the serum of stimulated animals (including humans) to achieve immediate immunization against infectious agents by administering pathogen-specific antibodies $[18,19]$. Convalescent blood products (CBP) are acquired from a patient who has survived a previous infection and developed humoral immunity against the pathogen responsible for the disease and their whole blood or plasma is used as a potential source of specific antibodies. CBP transfusion can neutralize the pathogen and ultimately eradicate it from the blood circulation [19]. Convalescent Plasma (CP) is collected via apheresis. For allowing a selective collection of plasma donor blood is going through continuous centrifugation and the procedure efficacy is around $400-800 \mathrm{~mL}$ from a single apheresis donation [20]. The component of CP (Figure 18) includes a wide range of blood-derived components, a mixture of organic compounds and inorganic salts, water, and more than thousands of proteins [21].

Though there is no standard transfusion dose of CP for coronavirus treatment is fixed, but according to ongoing research, currently, the recommendation is to administrate 3 


\section{DOCTOR'S RESPONSE}

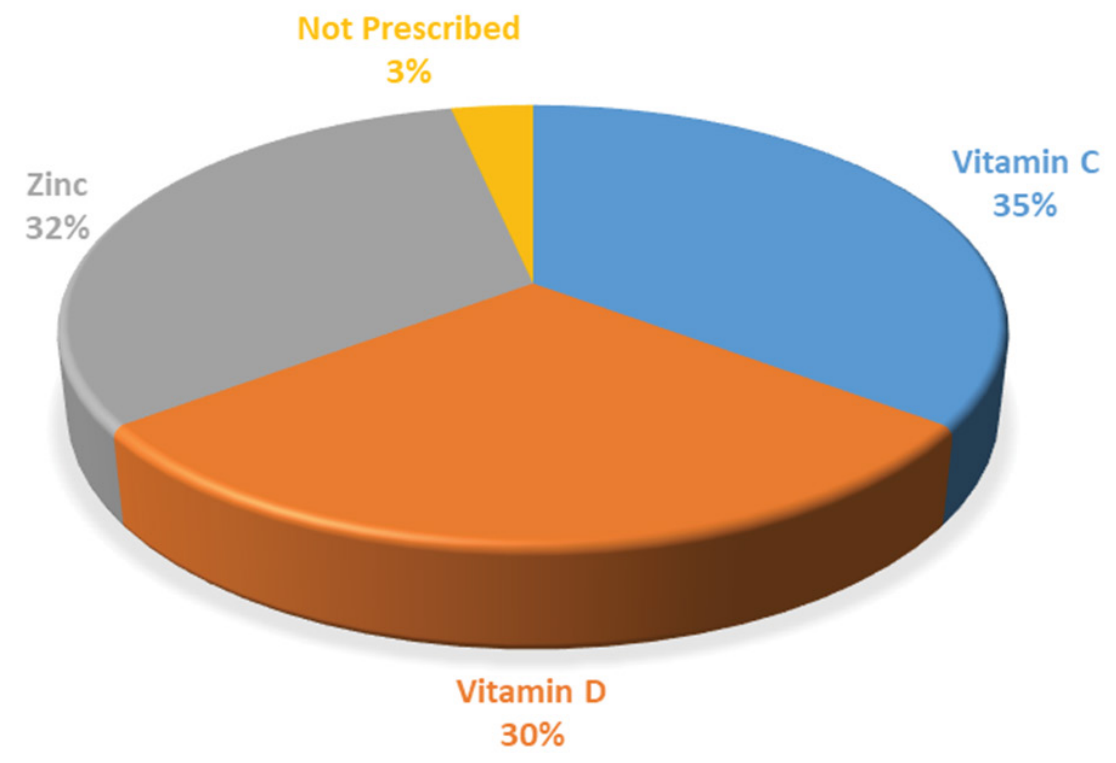

Figure 17: Doctors' responses about essential vitamins and minerals during COVID-19 outbreak.

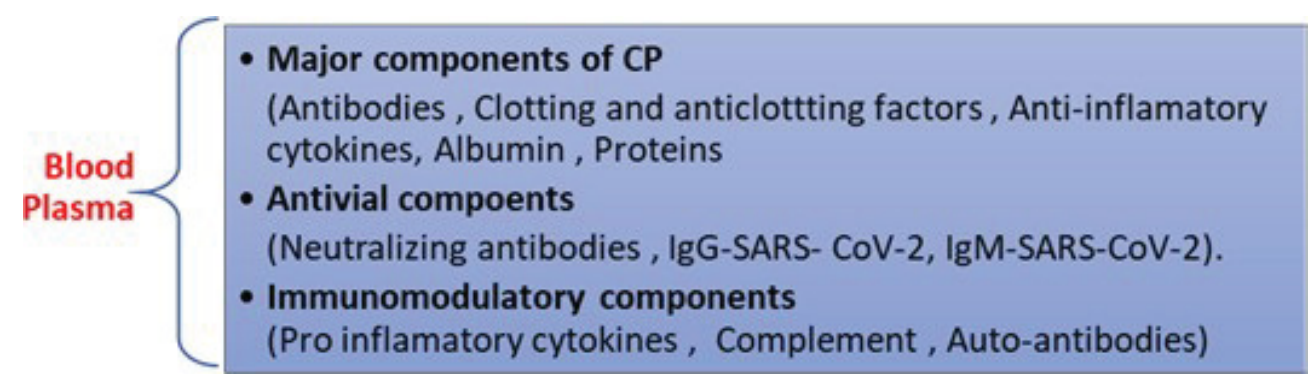

Figure 18: Components ingredients of blood plasma.

\section{How many COVID-19 positive cases need plasma therapy?}

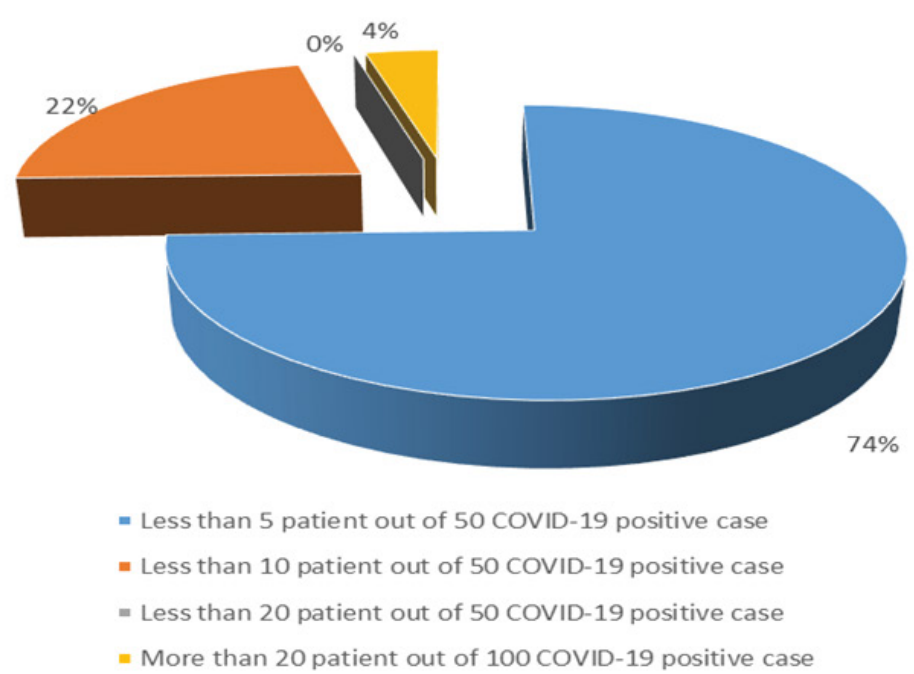

Figure 19: Doctors' responses about the approximate need for plasma therapy for COVID-19 cases. 
Citation: Rashid F, Ashrafuzzaman , Ayesha SKL, et al. (2020) An Approximate Overview of COVID-19 Treatment Approaches by Registered Physicians of Bangladesh. Insights Biomed Res 4(1):125-138

$\mathrm{mL} / \mathrm{kg}$ per dose in two days [22]. As per current regulations, the donor has to within 18 to 65 years old who recently recovered from COVID-19 without any further symptoms of infectious and a negative test for COVID-19 after 14 days of recovery. During donation and 48 hours later the test must be repeated. Besides donors be free from any blood-borne infection like HIV, HBV, HCV, syphilis, tuberculosis, malaria, typhoid as per current regulations $[23,24]$. Due to the deficiency of appropriate donors, inadequate expert to handling this therapy, lack of proper collection and preservation method and mismanagement, etc. became influencing factors. During the survey in the last three months among registered doctors of Bangladesh, $74 \%$ of them have suggested less than 5 patients out of 50 COVID-19 positive cases need plasma therapies (Figure 19). However, the need for plasma therapy is increasing day by day due to its immediate response find in different researches (Table 2).

Table 2: Overall summary of the results obtained thorough questionnaire form.

\begin{tabular}{|c|c|c|c|c|c|c|}
\hline \multicolumn{7}{|l|}{ Prescribed Medicines } \\
\hline \multicolumn{7}{|l|}{ For suspected cases } \\
\hline \multicolumn{2}{|l|}{ Antibiotics } & \multicolumn{2}{|l|}{$\begin{array}{l}\text { No } \\
68 \%\end{array}$} & \multicolumn{3}{|l|}{$\begin{array}{l}\text { Yes } \\
32 \%\end{array}$} \\
\hline \multicolumn{2}{|l|}{ Ivermectin } & \multicolumn{2}{|l|}{$\begin{array}{l}\text { Yes } \\
54 \%\end{array}$} & \multicolumn{3}{|l|}{$\begin{array}{l}\text { No } \\
46 \%\end{array}$} \\
\hline \multicolumn{7}{|l|}{ For confirmed cases } \\
\hline \multicolumn{2}{|l|}{ Antibiotics } & \multicolumn{2}{|l|}{$\begin{array}{l}\text { Yes } \\
82 \%\end{array}$} & \multicolumn{3}{|l|}{$\begin{array}{l}\text { No } \\
18 \%\end{array}$} \\
\hline \multicolumn{2}{|l|}{ Ivermectin } & \multicolumn{2}{|c|}{$\begin{array}{l}\text { Not prescribed } \\
46 \%\end{array}$} & \multirow[t]{2}{*}{$\begin{array}{l}\text { No } \\
28 \%\end{array}$} & \multicolumn{2}{|l|}{$\begin{array}{l}\text { Yes } \\
26 \%\end{array}$} \\
\hline \multicolumn{6}{|c|}{ For suspected/confirmed cases } & \\
\hline \multicolumn{2}{|l|}{ Hydroxychloroquine } & \multicolumn{2}{|l|}{$\begin{array}{l}\text { No } \\
82 \%\end{array}$} & \multicolumn{3}{|l|}{$\begin{array}{l}\text { Yes } \\
18 \%\end{array}$} \\
\hline \multicolumn{2}{|l|}{ Antiviral drugs } & \multicolumn{2}{|l|}{$\begin{array}{l}\text { No } \\
72 \%\end{array}$} & \multicolumn{3}{|l|}{$\begin{array}{l}\text { Yes } \\
28 \%\end{array}$} \\
\hline \multicolumn{7}{|c|}{ Recommended Medicines } \\
\hline \multicolumn{7}{|l|}{ For suspected cases } \\
\hline $\begin{array}{l}\text { NSAID except } \\
\text { Paracetamol }\end{array}$ & \multicolumn{2}{|l|}{$\begin{array}{l}\text { None } \\
90 \%\end{array}$} & $\begin{array}{l}\text { Yes but others } \\
6 \%\end{array}$ & $\begin{array}{l}\text { Aceclofenac } \\
4 \%\end{array}$ & \multicolumn{2}{|l|}{$\begin{array}{l}\text { Naproxen } \\
0 \%\end{array}$} \\
\hline $\begin{array}{l}\text { Commonly } \\
\text { prescribed medicines }\end{array}$ & \multicolumn{2}{|c|}{$\begin{array}{l}\text { Paracetamol and } \\
\text { antihistamine } \\
84 \%\end{array}$} & $\begin{array}{l}\text { Paracetamol } \\
10 \%\end{array}$ & $\begin{array}{l}\text { Others } \\
6 \%\end{array}$ & \multicolumn{2}{|l|}{$\begin{array}{l}\text { Antihistamine } \\
0 \%\end{array}$} \\
\hline Antiviral drugs & \multicolumn{3}{|c|}{$\begin{array}{l}\text { Favipiravir } \\
65 \%\end{array}$} & \multicolumn{3}{|l|}{$\begin{array}{l}\text { Remdesivir } \\
35 \%\end{array}$} \\
\hline $\begin{array}{l}\text { Vitamins and } \\
\text { minerals }\end{array}$ & \multicolumn{2}{|l|}{$\begin{array}{l}\text { Vitamin C } \\
35 \%\end{array}$} & $\begin{array}{l}\text { Zinc } \\
32 \%\end{array}$ & $\begin{array}{l}\text { Vitamin D } \\
30 \%\end{array}$ & \multicolumn{2}{|l|}{$\begin{array}{l}\text { Not prescribed } \\
3 \%\end{array}$} \\
\hline \multicolumn{7}{|l|}{ For confirmed cases } \\
\hline Common antibiotics & \multicolumn{2}{|l|}{$\begin{array}{l}\text { Both } \\
38 \%\end{array}$} & $\begin{array}{l}\text { Azithromycin } \\
26 \%\end{array}$ & $\begin{array}{l}\text { Doxycycline } \\
18 \%\end{array}$ & \multicolumn{2}{|l|}{$\begin{array}{l}\text { Others } \\
18 \%\end{array}$} \\
\hline Other antibiotics & $\begin{array}{l}\text { Meropena } \\
37 \%\end{array}$ & & $\begin{array}{l}\text { Amoxicillin/Cefuroxium } \\
+ \text { clavulanic acid } \\
22 \%\end{array}$ & $\begin{array}{l}\text { Ceftriaxone/ } \\
\text { Cefuroxime } \\
19 \%\end{array}$ & $\begin{array}{l}\text { Moxifloxacin } \\
16 \%\end{array}$ & $\begin{array}{l}\text { Levofloxacin } \\
6 \%\end{array}$ \\
\hline ICU used drugs & $\begin{array}{l}\text { Steroid } \\
35 \%\end{array}$ & & $\begin{array}{l}\text { Enoxaprin } \\
25 \%\end{array}$ & $\begin{array}{l}\text { Meropenem } \\
23 \%\end{array}$ & $\begin{array}{l}\text { Antiviral } \\
17 \%\end{array}$ & \\
\hline
\end{tabular}


Citation: Rashid F, Ashrafuzzaman , Ayesha SKL, et al. (2020) An Approximate Overview of COVID-19 Treatment Approaches by Registered Physicians of Bangladesh. Insights Biomed Res 4(1):125-138

\begin{tabular}{|c|c|c|c|c|}
\hline Bronchodilator & $\begin{array}{l}\text { Salbutamol } \\
42 \%\end{array}$ & $\begin{array}{l}\text { None } \\
24 \%\end{array}$ & $\begin{array}{l}\text { Both } \\
20 \%\end{array}$ & $\begin{array}{l}\text { Ipratropium + Salbutamol } \\
14 \%\end{array}$ \\
\hline \multicolumn{5}{|c|}{ Non-medication treatment } \\
\hline $\begin{array}{l}\text { Ventilator/ICU } \\
\text { Support }\end{array}$ & $\begin{array}{l}<10 \text { patients } \\
83 \%\end{array}$ & $\begin{array}{l}<30 \text { patients } \\
13 \%\end{array}$ & $\begin{array}{l}<50 \text { patients } \\
2 \%\end{array}$ & $\begin{array}{l}>50 \text { patients } \\
2 \%\end{array}$ \\
\hline Plasma therapy & $\begin{array}{l}<5 \text { patients } \\
74 \%\end{array}$ & $\begin{array}{l}<10 \text { patients } \\
22 \%\end{array}$ & $\begin{array}{l}>20 \text { patients } \\
4 \%\end{array}$ & $\begin{array}{l}<20 \text { patients } \\
0 \%\end{array}$ \\
\hline
\end{tabular}

\section{Do you treat COVID-19 suspected/positive patients in ICU during the last 3 months}

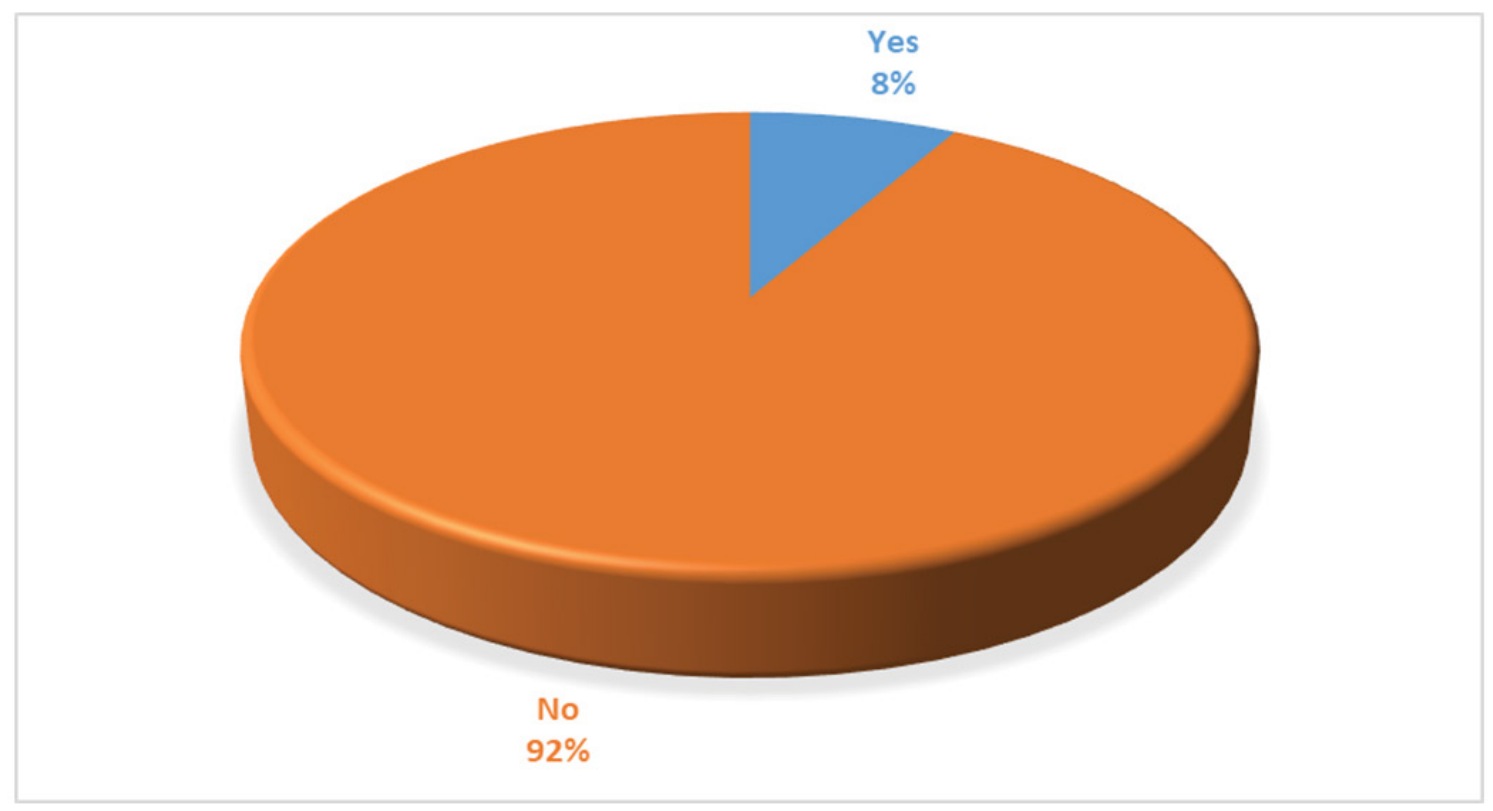

Figure 20: Doctors' responses about treating COVID-19 patients in ICU.

\section{Study Limitations}

There are several limitations was identified in our survey such as only 50 doctors are chosen as a sample which is very limited in respect of total registered physician of Bangladesh which is approximately 53000 (although all are not dedicated to COVID-19 treatment). Another drawback of our survey was the limited number of ICU doctors participating. Only $8 \%$ of participated physicians worked in ICU. The result is given in Figure 20. In Bangladesh, Clinical Trial and related research are administering by Bangladesh Medical Research Council (BMRC) specially for the ethical clearance and other are regulated by the own regulatory committee at different medical colleges and universities. We have mainly surveyed and analyzed the collected data to obtain specific findings, facing no other constraints IRB approval processes were not needed necessarily. Despite the limitation of the survey, we have tried to understand the paradigm of overall treatment approaches that are given by Bangladeshi doctors according to their medical knowledge and experience of practice during this COVID-19 pandemic situation.

\section{Conclusions}

The world is captured to the threat of a newly identified strand of coronavirus. This threat is now known to us $21^{\text {st }}$ centuries first pandemic (COVID-19 pandemic). After the influenza virus pandemic in the last centuries, almost the same flu-like sign symptoms are represented by a coronavirus in this current century's pandemic condition. Preventive measure is an all-time priority to the world health sectors leaders. Though vaccination is the definite preventive measure for most the viral infection, the WHO is continuously advising everyone to maintain proper personal preventive measure such as proper social distancing (at least 6 feet), frequent hand wash with soap and water or sanitize with $70 \%$ alcohol, use of a mask by everyone especially in a crowded place, etc. These preventive measures are necessary to reduce the spread of the virus from person to person. After the outbreak of coronavirus in the early months of 2020, different countries are trying to invent vaccines and for this reason, there is a wide range of research is still going on around the world and one or two countries are almost reach their desired destination.

Despite having lots of limitations to establish any vaccine by a developing country like Bangladesh, one of the countries pharmaceutical company "Globe BioTech Limited" has claimed success on preliminary animal modeling trial of covid19 vaccine and aiming to availability of vaccine in the 
Citation: Rashid F, Ashrafuzzaman , Ayesha SKL, et al. (2020) An Approximate Overview of COVID-19 Treatment Approaches by Registered Physicians of Bangladesh. Insights Biomed Res 4(1):125-138

market by December 2020 [25]. By this time, the frontline doctors of Bangladesh are continuously doing their responsibilities to serve this covid19 patient with their limited resources but with full dedication and efforts. This research work is done to unearth and analyze the estimated overall treatment protocol maintained by the registered physicians of Bangladesh. The Bangladeshi registered doctor's treatment approaches for COVID-19 patient is scientifically co-relate with the recent different research-based work on treatment protocol to combat this coronavirus pandemic situation. In the end, it is saying without a doubt that, regardless of various limitations in the health sectors of Bangladesh, the physicians of this country are serving this 16 million country people unconditionally for saving the nation from this deadly virus of the centuries.

\section{Acknowledgments}

The authors would like to acknowledge the support of the Biomedical Engineering Department, Military Institute of Science and Technology (MIST), Bangladesh.

\section{Conflict of Interest}

The authors declare that they have no conflict of interest.

\section{References}

1. (2019) Coronavirus disease 2019 (COVID-19) information Bangladesh. corona.gov.bd.

2. M Armour, K Lawson, A Wood, et al. (2019) The cost of illness and economic burden of endometriosis and chronic pelvic pain in Australia: A national online survey. PLOS ONE 14: e0223316.

3. Varun Agrawal, PS Garimella, SJ Roshan, et al. (2009) Questionnaire survey of physicians: Design and practical use in nephrology. Indian J Nephrol 19: 41-47.

4. Kumar Pravindra, Ashok Kumar Sah, Greesham Tripathi, et al. (2020) Role of ACE2 Receptor and the landscape of treatment options from convalescent plasma therapy to the drug repurposing in COVID-19. Molecular and Cellular Biochemistry.

5. E Rizzo (2020) Ivermectin, antiviral properties and COVID-19: A possible new mechanism of action. Naunyn-Schmiedeberg's Arch Pharmacol 393: 1153-1156.

6. K Intuyod, C Hahnvajanawong, P Pinlaor, et al. (2019) Antiparasitic drug ivermectin exhibits potent anticancer activity against gemcitabine-resistant cholangiocarcinoma in vitro. Anticancer Res 39: 4837-4843.

7. WC Campbell, GW Benz (1984) Ivermectin: A review of efficacy and safety. J Vet Pharmacol Ther 7: 1-16.

8. ATMM Chowdhury (2020) A comparative observational study on ivermectin and hydroxychloroquine on the covid19 patients in
Bangladesh. Clinicaltrials.gov.

9. TH Chang, LF Wang, YS Lin, et al. (2014) Hydroxychloroquine activates host antiviral innate immunity. Cytokine 70: 33-34.

10. REFerner,JKAronson(2020)Chloroquine and hydroxychloroquine in covid-19. BMJ 369.

11. (2020) icddr,b begins clinical trial of Ivermectin. The Daily Star.

12. (2020) icddr,b begins clinical trial of Ivermectin to treat patients with COVID-19. icddr,b - Press Releases.

13. ATMM Chowdhury, M Shahbaz, Md Rezaul Karim, et al. (2020) A comparative study on ivermectin- doxycycline and hydroxychloroquine-azithromycin therapy on COVID19 patients.

14. (2020) Efficacy and safety of favipiravir compared to the base therapeutic regiment in moderate to severe COVID-19: A randomized, controlled, double-blind, clinical trial. Clinicaltrials. gov.

15. Y Wang, D Zhang, G Du, et al. (2020) Remdesivir in adults with severe COVID-19: A randomised, double-blind, placebocontrolled, multicentre trial. The Lancet 395: 1569-1578.

16. R Jayawardena, P Sooriyaarachchi, M Chourdakis, et al. (2020) Enhancing immunity in viral infections, with special emphasis on COVID-19: A review. Diabetes \& Metabolic Syndrome: Clinical Research \& Reviews 14: 367-382.

17. (2020) Ask the expert: The role of diet and nutritional supplements during COVID-19. The Nutrition Source.

18. G Rajam, J Sampson, GM Carlone, et al. (2010) An augmented passive immune therapy to treat fulminant bacterial infections. Recent Pat Antiinfect Drug Discov 5: 157-167.

19. V Virdi, A Depicker (2013) Role of plant expression systems in antibody production for passive immunization. Int J Dev Biol 57: 587-593.

20. RJ Benjamin, LS McLaughlin (2012) Plasma components: Properties, differences, and uses: PLASMA COMPONENTS," Transfusion 52: 9S-19S.

21. J van Griensven, T Edwards, X de Lamballerie, et al. (2016) Evaluation of convalescent plasma for Ebola virus disease in Guinea. N Engl J Med 374: 33-42.

22. EM Bloch, S Shohem, A Casadevall, et al. (2020) Deployment of convalescent plasma for the prevention and treatment of COVID-19. J Clin Invest 130: 2757-2765.

23. $P$ Tiberghien, $X$ Lamballerie, $P$ Morel, et al. (2020) Collecting and evaluating convalescent plasma for COVID-19 treatment: Why and how? Vox Sang 115: 488-494.

24. JD Tissot, O Garraud (2016) Ethics and blood donation: A marriage of convenience. La Presse Médicale 45: e247-e252.

25. (2020) Bangladesh might have Covid-19 vaccine by december, says Globe Biotech scientist. Business Insider.

DOI: $10.36959 / 584 / 459$

Copyright: (C) 2020 Rashid F, et al. This is an open-access article distributed under the terms of the Creative Commons Attribution License, which permits unrestricted use, distribution, and reproduction in any medium, provided the original author and source are credited. 